\title{
PRODUCTIVITY AND THE DECISION \\ TO EXPORT: MICRO EVIDENCE FROM TAIWAN AND SOUTH KOREA
}

\author{
Bee Yan Aw \\ Sukkyun Chung \\ Mark J. Roberts
}

Working Paper 6558

http://www.nber.org/papers/w6558

\section{NATIONAL BUREAU OF ECONOMIC RESEARCH 1050 Massachusetts Avenue \\ Cambridge, MA 02138 \\ May 1998}

We appreciate the helpful comments of Richard Caves, J. David Richardson, Jim Tybout, and participants at the Conference on "Trade and Technology Diffusion" at the Fondazione Eni Enrico Mattei, Milan, Italy, and the NBER Summer Productivity Institute. Any opinions expressed are those of the authors and not those of the National Bureau of Economic Research.

(C) 1998 by Bee Yan Aw, Sukkyun Chung and Mark J. Roberts. All rights reserved. Short sections of text, not to exceed two paragraphs, may be quoted without explicit permission provided that full credit, including $(\mathcal{C}$ notice, is given to the source. 
Productivity and the Decision to Export: Micro

Evidence from Taiwan and South Korea

Bee Yan Aw, Sukkyun Chung and Mark J. Roberts

NBER Working Paper No. 6558

May 1998

JEL Nos. F14, O12, D24

\section{$\underline{\text { ABSTRACT }}$}

While there is widespread empirical evidence indicating exporting producers have higher productivity than nonexporters, the mechanisms that generate this pattern are less clear. One view is that exporters acquire knowledge of new production methods, inputs, and product designs from their international contacts, and this learning results in higher productivity for exporters relative to their more insulated domestic counterparts. Alternatively, the higher productivity of exporters may simply reflect the self-selection of more efficient producers into a highly competitive export market. In this paper we use micro data collected in the manufacturing censuses in South Korea and Taiwan to study the linkages between a producer's total factor productivity and choice to participate in the export market.

We find differences between the countries in the importance of selection and learning forces. In Taiwan, transitions of firms in and out of the export market reflect systematic variations in productivity as predicted by self-selection models. Firms with higher productivity, ex ante, tend to enter the export market and exporters with low productivity tend to exit. Moreover, in several industries, entry into the export market is followed by relative productivity improvements, a result consistent with learning-by-exporting forces. In South Korea, the evidence of self-selection on the basis of productivity is much weaker. In addition, unlike Taiwan, we find no significant productivity changes following entry or exit from the export market that are consistent with learning from exporting. Comparison of the two countries suggests that in Korea factors other than production efficiency play a more prominent role as determinants of the export decision.

Bee Yan Aw

Department of Economics Pennsylvania State University University Park, PA 16802 byr@psu.edu
Sukkyun Chung

Ministry of Finance \& Economy

Kwachon-Shi

Kyonggi-Do 427-760

REPUBLIC OF KOREA
Mark J. Roberts

Department of Economics Pennsylvania State University University Park, PA 16802 and NBER mroberts@psu.edu 


\section{Introduction}

Over the last three decades Taiwan and South Korea have seen high, sustained rates of growth in manufactured output. To understand the source of this output growth, beyond the input and productivity contributions identified in the growth accounting literature, development economists have focused on the role of the export market. At a minimum, the ability to export has allowed manufacturers to specialize in certain products or sectors and increase their output levels substantially beyond what could be supported by the size of their domestic market. A larger role for exports in the economic success of Korea and Taiwan may arise if exports serve as a conduit for technology transfer from abroad which, in turn, generates technological spillovers to the rest of the economy. This argument is supported by industry studies that document the knowledge flows from foreign buyers to domestic producers and by empirical evidence that finds that exporters are more efficient than their counterparts that sell primarily in the domestic market. The belief that the export activity generates cumulative productivity benefits is often cited as an argument for the active promotion of exports in many developing countries.

The empirical finding that exporters are more productive than nonexporters is widespread and robust, but only two recent papers have addressed the more complex issue of whether exports play a causal role in generating higher productivity. Clerides, Lach, and Tybout (forthcoming) examine this issue using manufacturing data for Colombia, Mexico, and Morocco while Bernard and Jensen (forthcoming) focus on U.S. manufacturers. They examine two mechanisms linking productivity and exporting. One is that exporters learn from their contacts in the export market and this results in the adoption of better production methods and higher productivity. Alternatively, the higher productivity of exporting firms reflects the selfselection of more efficient producers into a highly competitive export market. Both papers find that the self-selection of more efficient producers into the export market is an important part of the story in these countries and that there is little evidence of efficiency gains that could reflect learning that accrues from 
exporting.

In this paper we use micro data collected in the manufacturing censuses in Korea and Taiwan to study the link between a producer's total factor productivity and choice to participate in the export market. We focus on the relationship between productivity and the movements of producers in and out of the export market because different transition patterns, rather than just different exporting status, are crucial to separating the selection and learning explanations. If self selection is important then a producer's initial productivity should be reflected in subsequent movements in or out of the export market. If learning-byexporting is important then producers who choose to enter the market should have subsequent productivity changes that are different than producers who do not enter.

Our empirical results indicate that exporters in both countries have higher productivity than nonexporters at a point in time, but there are differences between the countries in the importance of selection and learning forces. In Taiwan, movements of firms in and out of the export market reflect systematic differences in productivity as predicted by models of self selection. There is also evidence of productivity improvements following entry into the export market in several industries, and this is consistent with the learning-by-exporting forces. In South Korea there is much weaker evidence of the self-selection of more efficient incumbent plants into the export market. Also, unlike Taiwan, we find no productivity changes following entry into or exit from the export market that would be consistent with learning from exporting. In the next section of the paper we summarize a theoretical model of producer turnover and market selection and outline the empirical implications we will examine using micro data for Taiwan and Korea. In the third section we summarize the average differences in total factor productivity between exporting and nonexporting plants. In the fourth section we summarize productivity differences across groups of plants with different transition patterns in and out of the export market. The final section provides a summary and conclusion. 


\section{The Relationship Between Productivity and Exporting}

There is a large body of empirical evidence that demonstrates that firms that participate in the export market are "better", more productive, larger, survive longer and pay higher wages, than firms that do not. ${ }^{1}$ At least two different mechanisms have been proposed that can explain the positive correlation between exporting and productivity. First, it can simply reflect the fact that only the most productive firms are able to survive in highly competitive export markets. If the fixed costs of selling in the export market are higher than for the domestic market or if output prices are lower, only high productivity firms will find it profitable to enter the export market in the first place and exporters whose productivity declines will be forced to exit. We will refer to this as the self-selection hypothesis. Second, the correlation can reflect productivity improvements that result from knowledge and expertise which the firm gains as a direct result of its export market experience. It has been argued that firms that participate in the export market have access to technical expertise, including both new product designs and production methods, from their buyers which nonexporters do not have. This phenomenon of learning-by-exporting may be particularly relevant for the East Asian countries. ${ }^{2}$

Both mechanisms are plausible but their actual importance is likely to vary across countries and industries with differences in the rates of product and process innovation, which alter the possibilities for learning, and the nature of trade policy, which can alter the strength of market selection forces. Two recent papers find clear evidence that, among exporters in Colombia, Morocco, and Mexico (Clerides, Lach, and Tybout, forthcoming) and the U.S. (Bernard and Jensen, forthcoming), self-selection is important. Firms

\footnotetext{
1 Papers examining the export-productivity relationship include Aw and Hwang (1995), Aw and Batra (1998), Chen and Tang (1987), Haddad (1993), Handoussa, Nishimizu and Page (1986), and Tybout and Westbrook (1995). Aw and Batra (forthcoming) and Bernard and Jensen (1995) examine the relationship between exports, firm size, and wages. Richardson and Rindal $(1995,1996)$ summarize the empirical evidence for a wide range of firm characteristics that are correlated with the exporting activity.

2 See Evenson and Westphal (1995), Grossman and Helpman (1991), Rhee, Ross-Larson, and Pursell (1984), and World Bank (1993) for discussion and evidence on the role of buyers in providing technical expertise.
} 
that become exporters are more efficient prior to entry than their nonexporting counterparts. In addition, both papers find little evidence of efficiency gains that could reflect learning-by-exporting. Clerides, Lach, and Tybout find that a producer's exporting history does not significantly alter current production costs. Bernard and Jensen find that future productivity growth is not significantly higher for plants that currently export. $^{3}$ Overall, the evidence weighs heavily on the self-selection of the more efficient firms into the export market as the main source of the productivity differences between exporters and nonexporters.

In this paper we use micro data for producers in the major Taiwanese and Korean exporting industries to examine the importance of the selection and learning-by-exporting forces. We construct an index of total factor productivity for each producer and examine how it varies across producers with different degrees of exposure to the export market. Particular attention is devoted to productivity differences between groups of producers classified by their movements in and out of the export market. Productivity differences between producers with different transition patterns, rather than just different exporting status, are crucial to separating the selection and learning explanations.

\section{Theoretical Framework}

To organize our empirical analysis of productivity and the decision to export, we rely on the recent model of firm and market dynamics developed by Hopenhayn (1992). ${ }^{4}$ While not specific to the export market, Hopenhayn models how firms with different levels of productivity will be led to make different

3 They do find that employment growth and the probability of survival are higher for exporting plants. The latter pattern can reflect the same underlying differences in efficiency that led to self selection into the export market and does not necessarily reflect improvements that follow as a result of exporting experience.

${ }^{4}$ A number of recent theoretical models of industry dynamics have been developed to explain the divergent paths of growth and failure that characterize micro data on individual producers. These models all begin with the assumption that producers within the same industry differ in their productive efficiency and are subject to idiosyncratic shocks or uncertainty. Differences in the evolution of their productivity over time, in turn, lead producers to make different decisions regarding entry, growth, and exit. The actual source of uncertainty differs across models with Jovanovic (1982) emphasizing firm uncertainty about their own productivity level, Lambson (1991) focusing on uncertain future market conditions, Hopenhayn (1992) emphasizing randomness in productivity changes over time, and Ericson and Pakes (1995) modeling uncertainty in the return to firm investments. 
decisions to enter, exit, or continue in a market. It allows us to identify how self-selection will lead to differences in the productivity of entering, exiting, or continuing cohorts of firms.

Hopenhayn models a market that is composed of a large number of price-taking firms that produce a homogeneous output. Firms differ in their efficiency with each firm's output depending on a random productivity shock, $\theta$, which follows a Markov process that is independent across firms. The distribution of future productivity is described by the distribution function $F\left(\theta_{t+1} \mid \theta_{t}\right)$, which is assumed to be strictly decreasing in $\theta_{\mathrm{t}}$. This assumption implies that, relative to a firm with low $\theta_{\mathrm{t}}$, a firm with high productivity in year $\mathrm{t}$ has a larger probability of having high productivity in year $\mathrm{t}+1$.

Each period, before the new productivity shock is observed, incumbent firms may choose to exit the market or remain in and pay a fixed cost, after which they observe their productivity shock, and choose their output level for that period. Potential entrants may choose to enter by paying a sunk entry cost, after which they draw their initial productivity level from a common distribution function $G(\theta)$, and choose their output level. Output prices are determined competitively to equate demand and supply. The key endogenous variables produced by the model are the flow of entrants into the market each period and the minimum productivity level needed for an incumbent firm to remain in the market. This productivity level, which we denote $X_{t}$, is the lowest productivity which will result in positive expected profits for the firm over future periods.

This model makes predications about differences in the average productivity of entering, exiting, and surviving producers. Hopenhayn demonstrates that firms will exit the market after period $t$ if $\theta_{t}<X_{t}$. The current period productivity $\theta_{\mathrm{t}}$, which the firm observes, determines the likely future trajectory of productivity through the distribution function $\mathrm{F}\left(\theta_{\mathrm{t}+1} \mid \theta_{\mathrm{t}}\right)$. Firms with $\theta_{\mathrm{t}}<\mathrm{X}_{\mathrm{t}}$ expect low future profit streams and exit after period t while firms with $\theta_{t}>X_{t}$ remain in the market. This implies that firm exit is concentrated among the least productive firms. This can be tested empirically for the export market by examining exporters in period $\mathrm{t}$ and asking if there are systematic differences in productivity between the 
group that continue exporting in $\mathrm{t}+1$ and the group that exit.

The model also allows comparisons between the productivity of a cohort of new entrants and cohorts of older surviving proudcers. The productivity of the new entrants is determined by the distribution function for initial productivity $\mathrm{G}(\theta)$. The productivity of older cohorts also reflects the failure of the least productive members over time and the random changes in the survivors' productivity over time. Hopenhayn demonstrates that if $F\left(\theta_{t+1} \mid \theta_{t}\right)$ is strictly decreasing in $\theta_{t}$ then the productivity distribution of any surviving cohort stochastically dominates the productivity distribution of the entering cohort. We can examine this empirically by comparing the productivity of new exporters and incumbent exporters at a point in time.

In the formal model all firms make their entry decision based only on knowledge of the distributions of initial productivity $G(\theta)$ and its evolution over time $F\left(\theta_{t+1} \mid \theta_{t}\right)$ and not on information about their own productivity level. In the case of the export market, many of the potential entrants will be currently producing in the domestic market and thus have better information on their likely productivity after entry than a firm with no prior experience. This should result in domestic producers with high productivity in year $t$ being more likely to enter the export market than low productivity domestic producers. We can examine this empirically by focusing on the producers that initially produce only in the domestic market and asking if the ones that subsequently enter the export market have higher initial productivity than those that remain specialized in the domestic market.

While Hopenhayn's model clarifies the important role of firm heterogeneity and self selection in generating flows of firms in and out of a market, it does not incorporate the idea that productivity may change following entry as described in the learning-by-exporting hypothesis. Clerides, Lach, and Tybout (forthcoming) incorporate this factor into a model of a domestic firm's decision to diversify into the export market. The entry decision is based on a comparison of the expected future profits, which depend on the firm's current and future productivity, with the sunk costs of entry. The effect of learning-by-exporting is 
incorporated by making a firm's current productivity depend on prior export experience.

The authors include a set of simulation results which provide useful insights into the interaction of selection and learning forces. They find that firms that enter or remain in the export market always have higher productivity than firms that stop exporting or remain only in the domestic market. When compared with firms that produce only in the domestic market, firms that enter the export market also have higher productivity prior to entry. Both of these patterns result because firms self select into the export market based on current productivity. When learning-by-exporting is added to the framework, the gap between the productivity of firms that enter the export market and those that do not continues to widen after entry. This latter pattern can be examined empirically by comparing the pre- and post-entry productivity differentials between entrants and nonentrants.

\section{Empirical Implications in Korea and Taiwan Micro Data}

To separate the selection and learning effects, Clerides, Lach, and Tybout (forthcoming) use plantlevel panel data with a relatively long time-series component to estimate a two-equation model consisting of the plant's decision to participate in the export market and the plant's cost function. The micro data which we have for Korea and Taiwan does not have sufficient time-series observations to allow us to use their approach. The Taiwan data set contains firm-level observations on the manufacturing sector in 1986 and 1991. The Korean data set contains observations for manufacturing plants in 1983, 1988, and 1993. While the number of time observations is not large, these data sets allow us to observe productivity differences over longer time periods which helps to reduce the role of transitory shocks, cyclical fluctuations, and measurement errors which can affect productivity comparisons based on higher frequency data.

Our empirical strategy, which is similar to the approach of Bernard and Jensen (forthcoming), is to compare the average productivity of groups of firms that have undergone different transition patterns. 
As indicated by Hopenhayn's model, self selection implies that the firms' period t productivity level should be a determinant of export market participation in year $\mathrm{t}+1$. The learning-by-exporting explanation implies that initial productivity differences between firms that select into the market and firms that do not should widen following entry or as they accumulate more export market experience. We will focus on changes in the period $t$ and $t+1$ differentials between exporters and nonexporters to isolate this effect.

There are a number of explanations besides learning-by-exporting for why the productivity of exporters will change more than the productivity of nonexporters over time. If entry into the export market allows firms to expand output and take advantage of economies of scale in production then exporters will be observed to have larger increases in productivity than nonexporters. In general, any factor that results in positive serial correlation in the shocks to firm-level productivity will generate this result. Firms with positive shocks to their productivity are more likely to find it profitable to enter the export market and if these positive shocks continue over time the productivity of exporters will continue to diverge from the nonexporters. Given our data we will not be able to distinguish these alternative explanations, but a finding that productivity differences between exporters and nonexporters do not diverge following entry is not consistent with any of these explanations, including learning-by-exporting.

To clarify the comparisons we make, define the following four groups of firms based on their export market participation in two adjoining years of data ${ }^{5}$ :

$\begin{array}{llll} & \text { Firm Status } & \text { Year } \mathrm{t} & \text { Year } \mathrm{t}+1 \\ \text { 1. } & \text { Stay Out } & \text { No exports } & \text { No exports } \\ \text { 2. } & \text { Entrant } & \text { No exports } & \text { Export } \\ \text { 3. } & \text { Exit } & \text { Export } & \text { No exports } \\ \text { 4. Stay In } & \text { Export } & \text { Export }\end{array}$

${ }^{5}$ In each of the cases where a firm is not exporting, it could reflect that the firm is selling only in the domestic market or that it is not in operation. These two groups will be distinguished in some of the comparisons made below. 
We will make five different comparisons based on this dichotomy. First, we will compare the productivity of exporters and nonexporters in each year in order to confirm the positive cross-sectional correlation between exporting and productivity. Second, we will compare the productivity of the four transition groups in the same year in order to see if the decision to participate in the export market reflects firm productivity. In both of these cases we will use all producers in operation in the year of interest. Thus, failing firms that exit production entirely after year $\mathrm{t}$ will be included in the year $\mathrm{t}$ comparisons and new firms that enter production after year $\mathrm{t}$ will be included in the year $\mathrm{t}+1$ comparisons.

The remaining comparisons will use the subset of firms that are in operation in both years because this allows us to compare improvements or declines in productivity with export market experience. The third comparison uses the nonexporters in year $\mathrm{t}$, groups 1 and 2 , and compares the year $\mathrm{t}$ and year $\mathrm{t}+1$ productivity between the two groups. If market selection is important we should see the year t productivity of the entrants, group 2, exceed the year t productivity of the firms that stay out, group 1 . The comparison of year $t+1$ productivity will reveal if the initial differentials narrow, widen, or remain unchanged after the one group has gained some experience in the export market. To the extent that learning is important we would expect to see this differential widen.

Fourth, to determine if productivity differentials persist following exit, we will compare the year $\mathrm{t}$ and $t+1$ productivity of groups 3 and 4 , firms that begin in the export market but follow different paths over time. If market selection is important then exit from the export market should be concentrated in the lower productivity producers. If exporting brings additional benefits then we should observe that the period $\mathrm{t}+1$ productivity differential widens between the group that remains exporters and the group that exits.

Fifth, to see if exporters follow different productivity paths than nonexporters over time we will compare the year $t$ and $t+1$ productivity of groups 1 and 4 , the firms that stay out and the firms that stay in. If the export market makes a difference to the accumulation of knowledge over time this will be reflected in an increasing divergence in productivity levels between these two groups. As a further refinement to this 
comparison, we ask if improvements over time accrue to new producers, since these are the ones most likely to benefit if learning effects are present. To do this we identify the producers in groups 1 and 4 that first begin in operation in year $t$ and then make the same comparison between year $t$ and $t+1$ productivity for the two groups.

\section{Productivity Differences Between Exporting and Nonexporting Producers}

The data set we analyze in this paper includes information collected as part of the manufacturing censuses in Taiwan and South Korea. In the case of Taiwan, observations are at the firm level for the Census years 1981, 1986, and 1991. However, for the industries we study between 80 and 90 percent of all Taiwanese firms are single-plant producers, so the distinction between plant and firm is not as important as in many industrialized countries. In the case of South Korea, we have plant-level observations for the years 1983 , 1988, and 1993. For simplicity we will refer to the data as plant level for both countries even though only firm-level information is available for Taiwan.

The data set contains information on output and inputs of capital, labor, and raw materials which allow us to construct an index of total factor productivity (TFP) for each plant. Details of the productivity index are given in the Appendix. In addition plant-level exports are reported for all three years in Korea and for 1986 and 1991 in Taiwan. ${ }^{6}$ The plant-level observations have been matched over time so that it is possible to identify entering and exiting producers in each census year. In addition, each producer can be classified by whether it is a nonexporter, an entrant to the export market, an incumbent exporter, or a firm that has exited the export market.

Given that our goal is to focus on the role of the export market as a source of knowledge and productivity differentials, we restrict our attention to the five two-digit industries that have a major export

\footnotetext{
${ }^{6}$ For Taiwan we observe the level of exports and domestic sales for each firm. For South Korea we have the value of plant sales and a set of categorical variables indicating whether the plant's export-sales ratio is high (over .75), medium (.25-.75), low (positive but less than .25), or zero.
} 
role in both Taiwan and South Korea. The industries, textiles, apparel, plastics, electrical machinery/electronics, and transportation equipment, have the highest export participation rates in the manufacturing sector. In Taiwan, this rate ranged from 26 percent in transportation equipment to 41percent in electrical machinery and electronics. In South Korea the share of firms that export ranges from 13 percent in apparel to 26 percent in electronics. In both Taiwan and South Korea these five industries account for more than half of total manufacturing exports in 1986 and 1988, respectively.

We begin by summarizing the cross-sectional differences in average productivity between the plants that sell in the export market and the group that operate solely in the domestic market. Table 1 reports the percentage difference in the average productivity of exporting and nonexporting plants by country, year, and industry. The first entry in the table indicates that in 1986 exporting plants in the textile industry in Taiwan had TFP levels that, on average, were 27.6 percent higher than nonexporting plants in the same industry. Across the five industries in Taiwan, exporters have average TFP levels that are between 11.8 percent (electrical machinery in 1986) and 27.6 percent (textiles in 1986) higher than nonexporters. All of the differences in means are statistically significant. A similar pattern of higher productivity among exporting plants is evident in Korea. In table 1, the average productivity difference between exporters and nonexporters varies from 3.9 percent (electrical machinery in 1988) to 31.1 percent (textiles in 1983) and all the differences are statistically significant.

The simple comparison of average productivity in table 1 clearly indicates the higher productivity of exporters relative to nonexporters in both countries. This result mirrors the finding for virtually every other country for which micro-level productivity comparisons have been done. Of course, the reason is unclear. If the domestic market is limited in size, then firms can benefit from entering the larger export market. However, higher levels of competition in world markets or higher fixed costs associated with selling in export markets means lower per unit profit streams, so that only the more efficient firms will enter and survive in the export market. Alternatively, if, once in the export market, firms can take 
advantage of scale economies or acquire knowledge of new technology that fosters learning, this will be reflected in higher productivity for exporters.

If these externalities from exporting exist, it is very likely that they are higher the greater the degree of exposure to the export market. We next ask if the productivity differential is an increasing function of the share of plant output that is exported or if the differential reflects an effect of "being in" that is independent of the degree of exposure. Table 2 reports regressions of plant productivity on year and export intensity dummies for each country and industry. The intercept represents the plants that do not export. The remaining coefficients measure the percentage difference in productivity between nonexporters and plants with low export intensity ( $<25$ percent of production exported), medium intensity ( 25 to 75 percent), and high intensity (>75 percent). The positive and significant coefficients on the export intensity dummies for both countries indicate clearly higher levels of productivity for exporting firms relative to nonexporters, as demonstrated in table 1 .

The new finding contained in table 2 is that differences in average productivity across groups of plants with different export intensities are very small, particularly when compared with the exporter/nonexporter differences. In Taiwan, for the textile and electrical machinery industries it is not possible to reject the hypothesis that average productivity is the same across all three export intensity categories. For the other three industries, we cannot reject that two of the three groups have equal average productivity. In addition, there is no consistent movement in the level of average productivity across intensity categories. For two industries productivity falls with increases in export intensity and for three industries it increases. Except for the apparel industry, the direction of change within industries is not monotonic across intensity categories.

These patterns are also evident in the Korean data. For three of the five industries, we do not reject that the three export categories have the same average productivity. In the textile and transportation industries there is evidence that the plants that export at least 75 percent of their output do have higher 
productivity. Average productivity among Korean textile plants that export less than one-quarter of their output is 18.8 percent higher than nonexporters and this differential rises to 28.1 percent for plants that export at least three-quarters of their output. In transportation equipment the low intensity category is 9.4 percent more productive than the nonexporters and the differential rises to 20.2 percent for the highest intensity category.

Overall, the cross-sectional results in tables 1 and 2 indicate that being an exporter, per se, signals higher productivity in every case, but the degree to which the firm's output is committed to the export market has little systematic effect on productivity for most of the industries.

\section{Turnover Patterns and Productivity}

\section{Productivity Differentials Between Transition Groups}

We now exploit the time series aspects of our data, and combine information on the transition patterns of firms in the export market with the cross-sectional productivity distribution. The regression results reported in table 3 compare the productivity of all plants in year $t+1$ based on their entry and exit status from the export market. The base category are the plants that do not export in either year, group 1 above. Columns 2-4 measure the percentage difference in average productivity between the three other categories and group 1. For Taiwan, there is an identical ranking of categories for all five exporting industries. The group with the lowest average productivity is the one that stays out of the export market in both years. These are followed, in order of increasing productivity, by the plants that exited the export market, the entrants, and the plants that stayed in the export market both years. Exiting plants, column 2, had average productivity levels that were 4.4 to 10.3 percent higher than the plants that never exported. Entrants, column 3, were, on average, 13.3 to 18.9 percent more productive than the nonexporters. Finally, plants that remained in the export market, column 4, were 16.7 to 22.3 percent more productive than nonexporters. 
The information in table 3 also summarizes the average productivity of the entrants and exits relative to firms that stay in the export market. Comparing columns 2 and 4, we see that the exits are between 11.4 percent and 15.5 less productive than the firms that remain in the export market. In addition, entrants are less productive than the experienced exporters. The difference between the column 3 and 4 numbers indicate that entrants are between 2.9 and 7.8 less productive than incumbents. Both of these patterns are consistent with the model of self selection outlined in the last section.

The patterns for Korea differ in some systematic ways from the results for Taiwan. First, in three industries, plastics, electrical machinery and transportation equipment, the average productivity of plants that exit the export market is not significantly different than the plants with no export market experience. Second, in two cases, textiles and apparel, the entrants are more productive than the incumbent exporters. Third, in the apparel industry the exiting plants have average productivity that is similar to the surviving plants. All these patterns indicate that, relative to Taiwan, differences in productivity are not as closely related to transitions in or out of the export market. ${ }^{7}$

Our finding that Taiwanese plants that exit the export market have higher average productivity than nonexporters differs from findings of studies for Colombia, Morocco, and Mexico by Clerides, Lach and Tybout (forthcoming) and the U.S. by Bernard and Jensen (forthcoming). They find that plants exiting the export market are among the worst performers. One explanation may be that the sunk costs

7 One additional refinement we make is to further divide the plants in year $t+1$ into new plants, those that first appear in production in year $t+1$, and old plants, those that were present in year $t$. In Taiwan the differences between the two groups are minimal with one exception. In the apparel industry, new plants that enter exporting have average productivity that is 10.0 percent higher than old plants that enter exporting. For Korea there are two cases where the differences are substantial. The new plants in textiles are approximately 16 percent more productive than the old plants and this differential holds for both exporters and nonexporters. In apparel, the new plants that enter exporting are an average of 14.3 percent more productive than old plants than begin exporting but there is no difference between new and old plants that do not export. The productivity difference between new and old plants can reflect the adoption of different technology in the new plants. Because this differential is observed for both exporters and nonexporters in Korean textiles it is unlikely that exporting is the conduit for the technology improvement. However, for the apparel industries only new exporting plants have the higher productivity and this raises the possibility that knowledge transfers resulting from contacts with foreign buyers could be the mechanism at work in this case. 
involved in re-entry into the export market in Taiwan are sufficiently low that plants do not hesitate to exit the market in the face of low productivity. In contrast, if the export market entry costs are higher in the other countries, producers will be more willing to continue in the export market in the face of low productivity and profits in order to wait and see if productivity improves. When sunk costs are high, the option value of remaining in operation in order to avoid the reentry costs is large. Only the firms with very low productivity will choose to exit when the entry costs are high. ${ }^{8}$

\section{Productivity Differentials Between Entrants and Nonentrants:}

We next focus on the plants that do not export in year t, groups 1 and 2, and compare the average productivity in $t$ and $t+1$ between the plants that enter the export market and the ones that remain out. The second column of Table 4 provides the percentage difference between these two groups in year $\mathrm{t}$ and column 3 reports the change in the differential in year $t+1$.

In every industry in Taiwan, firms that choose to enter the export market have significantly higher average productivity, prior to entry, than the firms that choose to stay out. The differential varies from 4.8 percent in electrical machinery to 14.8 percent in apparel. This is consistent with the self-selection hypothesis. As shown in column 3, the initial differential between the two groups of firms widens after entry in three of the industries, textiles, plastics, and electrical machinery. The increase in the productivity differential is between 6.0 and 8.3 percent. In the other two industries the change in the differential following entry is not statistically significant. For the three industries, the widening productivity differential is consistent with the learning-by-exporting hypothesis although, as noted above, this cannot be distinguished from other explanations that would generate positive serial correlation in productivity.

\footnotetext{
${ }^{8}$ Roberts and Tybout (1997) develop the empirical implications of sunk entry costs on plant-level export participation patterns. They find that sunk entry costs are an important determinant of exporting for Colombian manufacturing plants. Absence of a well-developed export trading sector was cited as one source of high entry costs. Campa (1998) finds that exporting sunk costs are also important for firms in the Spanish manufacturing sector. Levy (1991) argues that the well-developed network of trading firms in Taiwan acts to lower the entry costs of new exporters.
} 
Overall, the results for Taiwan clearly indicate that, among the continuing plants, productivity differences prior to entry are correlated with the entry decision and, in a number of industries, the plants that choose to enter continue to increase their productivity relative to nonentrants in the years following entry. The importance of self selection into the export market is similar to the findings of Bernard and Jensen (forthcoming) and Clerides, Lach and Tybout (forthcoming). None of the countries they examine, however, show evidence of the feedback effect of export market participation on productivity as found here.

In Korea the pattern is different. First, the positive coefficients in column 2 for all industries indicate that plants that choose to enter have higher productivity prior to entry than the nonexporters. The difference is statistically significant in three of the five industries, textiles, plastics, and transportation equipment, where the entrants are from 5.8 to 17.6 percent more productive. In addition, the results in column 3 indicate that the differential between entrants and nonentrants widens following entry but the change is never statistically significant. Thus, when compared with our findings for Taiwan, the statistical evidence in support of the self-selection and, particularly, the learning hypothesis is much weaker. The signs of the estimated coefficients are consistent with both effects but the results are not generally statistically significant.

\section{Productivity Differentials Between Exits and Survivors}

Table 5 summarizes the difference in productivity between plants that exit the export market and those that remain in, groups 3 and 4 . The second column reports the productivity differential in year $t$ when all the plants are in the export market. For Taiwan, the negative and significant coefficients indicate that the plants that will exit the export market after year $t$ are less productive than their counterparts that will continue exporting. The productivity gap varies from 6.2 to 13.1 percent. This is consistent with the self-selection hypothesis. The change in this differential between the same groups of plants in the census year following exit is reported in column 3. The negative coefficient in four of the five Taiwan industries 
indicates that the plants that exited the export market fell further behind the exporting ones in the years following exit. This widening of the productivity differential between exporting and nonexporting plants is statistically significant in three industries, plastics, electrical machinery, and transport equipment. Again, this is consistent with factors that lead to divergent productivity paths for exporting and nonexporting plants, of which learning by exporting is one.

For Korea, a similar pattern is identified but most of the differentials are not statistically significant. The column 2 coefficients indicate that exiting plants are significantly less productive than continuing exporters in two of the five industries, textiles, and electrical machinery, where the average productivity differential varies from 8.3 to 9.0 percent. The widening of the differential continues following exit for all but one industry, as shown in column 3, but this effect is not statistically significant in any of the industries. Overall, the statistical evidence that plants that exit the export market are less productive than continuing exporters and their relative position continues to deteriorate after exit is strong in Taiwan but much weaker in Korea. As was the case with entry, there is less evidence of either productivity-driven selection or productivity improvements correlated with export experience in Korea than in Taiwan.

\section{Productivity Differentials Between Long-Term Exporters and Nonexporters}

The final comparison we undertake is between plants that export in both years, group 4, and plants that never export, group 1. If the act of exporting results in higher productivity then we should observe the average productivity of these two groups diverge over time. Table 6 summarizes the average productivity differential in year $t$, column 2 , and how it changes in year $t+1$, column 3 . The results in column 2 identify the productivity premium of continuous exporters and largely replicate the productivity advantage of plants that remain in the export market identified in the last column of table 3. The results in column 3 indicate how this differential changes over time. They indicate that, for most industries, the productivity of these 
continuous exporters does not improve over time relative to the nonexporters. In three of the industries in Taiwan and all five industries in Korea there is no significant change in the productivity differential over time. In the two cases where there is a significant change in the relative productivity of the two groups, Taiwan's textile and apparel industries, the productivity advantage of the continuous exporters falls over time. Among the group of producers in operation for the two years there is no evidence that the average productivity of the continuous exporters rises relative to the firms with no export experience. There are large initial differences in productivity between the two groups but no evidence the differential widens with continued export experience. These results are not consistent with a process of ongoing learning-byexporting.

One possible reason that productivity differentials do not widen over time between continuous exporters and nonexporters is that both groups are a combination of plants of different ages. Learning may be concentrated among young or new plants, with older plants having already fully incorporated the knowledge acquired from their past experience. To determine if this is true we divide the plants in groups 1 and 4 into those that are new in year $t$ and those that were in operation (either in or out of the export market) in census year and examine the productivity differentials for the new plants. The results, which are not reported here, indicate that in the transportation equipment industry in Taiwan, the new plants that were continuous exporters had a productivity differential that widened by 8.1 percent in year $t+1$ relative to the new plants that never exported. This is the only example in Taiwan where we find that the productivity differential between the two groups widens over time. In addition, when we make this same comparison in Korea we find no industries where the export differential widened over time. Overall, with the exception of the transport equipment industry in Taiwan, this comparison provides no evidence that is consistent with the learning-by-exporting hypothesis. 


\section{Summary and Conclusion}

The relationships between firm-level total factor productivity and export experience are robust and simple to summarize for the five major exporting industries in Taiwan. On average, exporting firms have higher productivity than nonexporters. The transition patterns reflect systematic differences in productivity: average productivity is highest for continuing exporters followed by the group of entrants, exits, and nonexporters. Firms that diversify into the export market have higher productivity prior to entry than firms that choose not to enter and, in some industries, show evidence of productivity improvements following entry. Firms that will exit the industry are less productive than continuers and, in several industries, their relative position continues to deteriorate in the years following exit. Finally, for the group of continuous exporters there is no evidence their productivity advantage over firms that never export increases over time.

These results are very consistent with the self-selection of the higher productivity firms into the export market. There is also evidence for several industries that productivity differences between exporters and nonexporters widen as export experience accumulates but it is limited to firms that enter or exit the export market, not continuous exporters. This widening productivity gap could reflect direct benefits from exporting, such as knowledge spillovers from buyers, or other factors that lead to positive serial correlation in the shocks to firm productivity. In the latter case the firms with positive (negative) productivity shocks will transit into (out of) the export market and their productivity will continue to diverge from the group of firms that do not make any market transitions. Given the small number of time series observations in our data it is impossible to disentangle these two explanations, but, nonetheless, the patterns of productivity change post entry or exit are consistent with efficiency gains that accrue from the exporting process.

While exporters are, on average, more productive than nonexporters in South Korea, as in Taiwan, the productivity pattern of the cohorts transiting into and out of the export market differs significantly between the two countries. In several industries cohorts of new plants that enter the export market are 
more productive, on average, than older cohorts, suggesting that they may have access to different technology than older plants. Also, in several industries, plants that exit the export market have average productivity that is no different than plants that never exported, a pattern that is not observed in Taiwan. When focusing on continuing plants that diversify in or out of the export market, there is less evidence of productivity-based transitions in Korea than in Taiwan. For two of the five Korean industries, there are no significant differences prior to entry between plants that choose to enter and those that do not. Following entry there is no widening of the productivity differential in any of the five of the industries. Much of this pattern is also reflected on the exit side, in particular, there is no significant evidence that the productivity gap between plants that exit the export market and the ones that remain widen after exit. Finally, there is no evidence that the productivity advantage of the group of continuous exporters widens over time relative to producers that never export. Overall, these patterns are not supportive of the learning-by-exporting hypothesis and much less supportive of the self-selection hypothesis than are the findings for Taiwan.

Our empirical findings suggest that firm or plant productivity is less important as a determinant of export market participation in Korea than Taiwan. We expect a producer's decision to export to be based on the long-run expected profits they could earn in the export market. While total factor productivity is a very useful summary index of how a number of production-related factors such as the degree of capital utilization, importance of returns to scale, and managerial efficiency, vary across producers, it is not a perfect measure of long-run expected profits. If factors other than production efficiency are important determinants of expected profitability, and these differ substantially across producers, this will tend to weaken the correlation between a producer's productivity and pattern of export market transitions. These other factors could include product heterogeneity, entry costs, and government interventions that result in differential access to resources by producers.

If outputs are differentiated across producers then heterogeneity in both markups and productivity will contribute to differences in export profits and participation decisions. Hobday (1995) argues that there 
is little emphasis among Taiwanese manufactures on brand or product differentiation and little expenditure on advertising or R\&D. To the extent that export products are more homogenous in Taiwan than in Korea, profit differences and export decisions in Taiwan will more closely reflect differences in productive efficiency, as we find.

It has been argued by Pack (1992) and Levy (1991) that the dense network of subcontractors and export traders in Taiwan has lowered the costs of entry into and exit from the export market, particularly for small firms. In contrast, the weaker network of subcontractors and traders in South Korea imply higher initial investment costs by the producer, which can introduce hysteresis into the export decision. In this case the producer's prior export experience becomes an important determinant of the decision to export and this will weaken the link between current productivity and exporting choice.

Finally, a number of researchers including Pack and Westphal (1986), Westphal (1990), Levy (1991), and Rodrik (1995) have documented the importance of government investment subsidies in Korea. These policies have resulted in the channeling of credit at negative interest rates to South Korea's conglomerates and provided them with insurance against business risk, particularly in the export market. In this context, decisions of South Korean producers to enter, continue or exit the export market are less likely to be closely linked to productivity and more closely related to whether they have access to the necessary finance, contacts, or insurance provided by the government. While these investment subsidies have been reduced significantly in the 1980s, they are likely to have long term effects on participation decisions particularly in the presence of substantial entry costs. 


\section{Appendix I: The Measurement of Plant-Level Total Factor Productivity}

Using the manufacturing data for Taiwan and South. Korea, we construct an index of total factor productivity $(T F P)$ for each plant in each year. In the case of Taiwan, this is done for each of the three census years 1981, 1986, and 1991. ${ }^{9}$ For South Korea the three census years are 1983, 1988 and 1993.

A multilateral index which is useful for measuring TFP in plant- or firm-level panel data sets was developed by Caves, Christensen, and Diewert (1982). The TFP index is constructed as the log of the plant's output minus a revenue-share weighted sum of the log of the plant's inputs. In order to guarantee that comparisons between any two plant-year observations are transitive each plant's inputs and outputs are expressed as deviations from a single reference point. As the reference point the Caves, Christensen, and Diewert multilateral index uses a hypothetical plant with input revenue shares that equal the arithmetic mean revenue shares over all observations and output and input levels that equal the geometric mean of output and the inputs over all observations. Each plant's output, inputs, and thus productivity in each year is measured relative to this hypothetical plant. Good, Nadiri, and Sickles (1996) discuss an extension of the multilateral index that uses a separate hypothetical-plant reference point for each cross-section of observations and then chain-links the reference points together over time in the same way as the conventional Tornqvist index of productivity growth. This productivity index is useful in our application because it provides a consistent way of summarizing the cross-sectional distribution of plant $T F P$, using only information specific to that time period, and how the distribution moves over time.

Let each plant $f$ produce a single output $Y_{f t}$ using the set of inputs $X_{i f t}$ where $\mathrm{i}=1,2, \ldots \mathrm{n}$. The total factor productivity index for plant $f$ in year $t$ is defined as:

9 Tybout (1996) discusses alternative productivity measures based on econometric estimation of production functions and summarizes the literature on the sources of productivity differences across producers. 


$$
\begin{aligned}
\ln T F P_{f t} & =\left(\ln Y_{f t}-\overline{\ln Y_{t}}\right)+\sum_{s=2}^{t}\left(\overline{\ln Y_{s}}-\overline{\ln Y_{s-1}}\right) \\
& -\left[\sum_{i=1}^{n} \frac{1}{2}\left(S_{i f t}+\overline{S_{i t}}\right)\left(\ln X_{i f t}-\overline{\ln X_{i t}}\right)\right. \\
& \left.+\sum_{s=2}^{t} \sum_{i=1}^{n} \frac{1}{2}\left(\overline{S_{i s}}+\overline{S_{i s-1}}\right)\left(\overline{\ln X_{i s}}-\overline{\ln X_{i s-1}}\right)\right]
\end{aligned}
$$

The first line of the formula measures plant output and consists of two parts. The first part expresses the plant's output in year $t$ as a deviation from the reference point, the geometric mean output over all plants in year $t$, thus capturing information on the cross-sectional distribution in output. The second part sums the change in the output reference point across all years, effectively capturing information on the shift of the output distribution over time by chain-linking the movement in the reference point. The remaining two lines of the formula perform the same operation for each input $X_{i}$. The inputs are then summed using a combination of plant revenue shares $S_{i f t}$ and average revenue shares $S_{i t}$ in each year as weights. The index provides a measure of the proportional difference in TFP for plant $f$ in year $t$ relative to the hypothetical plant in the base year. In our application we use 1981 as the base year for Taiwan and 1983 as the base year for Korea.

\section{Appendix II: Description of the Data ${ }^{10}$}

The Taiwanese data used in this paper are a compilation of the last three Industrial and Commercial Census collected by the Statistical Bureau of Taiwan's Executive Yuan. They cover the years 1981, 1986 and 1991. The Statistical Bureau collects detailed data on each of the firms in operation in the manufacturing sector, which is more than 88,000 firms in 1981 and over 100,000 manufacturing firms in

10 Aw, Chen, and Roberts (1997) provide a more detailed discussion of the Taiwan data and the construction of inputs and outputs used in productivity measurement. 
each of the latter two Census years. The data for South Korea comes from the last three Censuses of Manufactures for 1983, 1988, and 1993. They cover all manufacturing plants with more than five employees in each of the 23 industries defined at the 2-digit SITC level. There are approximately 39,022 plants in 1983, with that number increasing to 59,732 and 88,864 in 1988 and 1993, respectively.

The firm or plant observations for each country not only provide complete cross-sectional coverage of the manufacturing sector but are matched across the censuses so that individual producers can be followed over time and entry and exit patterns observed. The Censuses for both countries provide information on the output and input variables that are necessary to measure total factor productivity at the firm or plant-level: sales, employment, book value of the capital stock, and expenditures on labor and different types of intermediate inputs. The type of data that is collected in both countries is very similar and we will discuss the variable construction for both countries at the same time, noting differences where relevant. ${ }^{11}$

For Taiwan, firm output is defined as total firm sales deflated by a wholesale price index defined at the two-digit industry level. For Korea, the value of plant output is measured as the sum of total revenues from sales, repairing and fixing services, the revenue from subcontracted work, and the change in the inventory of final goods. It is deflated by a producer price index defined at the two-digit industry level.

We model each producer as using four inputs in production: labor, capital, materials, and subcontracting services. The labor input is measured as the number of production plus non-production workers. Total payments to labor are measured as total salaries to both groups. The measure of capital input is the book value of capital stock of the firm or plant. We have adjusted the book values to control for price level changes in new capital goods that will cause the book value to change over time with investment in new equipment. The expenditure share on capital is calculated as the residual after

\footnotetext{
11 The type of data collected in the Taiwan manufacturing census is very similar to what is collected in the United States (see Baily, Hulten, and Campbell (1992) for its use in productivity measurement) or in the developing countries analyzed in Roberts and Tybout (1996).
} 
subtracting the expenditure on labor, material inputs, and subcontracting from the value of output.

The material input is defined to include raw materials, fuel, and electricity. In Taiwan, raw material expenditures are deflated by a general producer price index which covers both manufacturing and nonmanufacturing output in the country. Fuel and electricity expenditures are deflated by an aggregate energy price index. In Korea, we use a raw material price index for the manufacturing sector to deflate material expenditures. Fuel expenditures are deflated by an energy producer price index and electricity expenditure is deflated by an electricity price index.

The final input is a measure of expenditure on subcontracting services. Many producers in both countries hire subcontractors to perform pieces of the manufacturing process and payments to these subcontractors are reported as a separate expenditure by the firm or plant in the census data. To construct a subcontracting input we deflate the payments to subcontractors by the output price of the industry in which the firm or plant operates. While this is not an ideal price index to use in deflating subcontracting expenditures, the overall inclusion of the subcontracting input is important since it recognizes that the inputs of producers that subcontract some of the production steps need to be increased, and thus their TFP reduced, relative to the producers that do not subcontract. 


\section{References}

Aw, Bee Yan, and Geeta Batra (1998), "Technology, Exports and Firm Efficiency in Taiwanese Manufacturing." Economics of Innovation and New Technology, 5, 1-21.

Aw, Bee Yan, and Geeta Batra (forthcoming), "Wages, Firm Size and Wage Inequality: How Much Do Exports Matter?" in Innovation, Industry Evolution, and Employment, D.B. Audretsch and R. Thurik (eds.), Cambridge: Cambridge University Press.

Aw, Bee Yan, Xiaomin Chen, and Mark J. Roberts (1997), "Firm-Level Evidence on Productivity Differentials, Turnover and Exports in Taiwanese Manufacturing," NBER working paper No. 6235.

Aw, Bee Yan and Amy Hwang (1995), "Productivity and the Export Market: A Firm-Level Analysis," Journal of Development Economics, 47, 313-332.

Baily, Martin Neil, Charles Hulten, and David Campbell (1992), "Productivity Dynamics in Manufacturing Plants," Brookings Papers on Economic Activity: Microeconomics 1992, 187-267.

Bernard, Andrew B. and J. Bradford Jensen (1995), "Exporters, Jobs, and Wages in U.S. Manufacturing, 1976-1987,” The Brookings Papers on Economic Activity: Microeconomics 1995, 67-112.

Bernard Andrew B. and J. Bradford Jensen (forthcoming), "Exceptional Exporter Performance: Cause, Effect, or Both?" Journal of International Economics.

Campa, Jose (1998), “Exchange Rates and Trade: How Important is Hysteresis in Trade?” Working paper, Stern School of Business, New York University.

Caves, Douglas W., Laurits Christensen, and Erwin Diewert (1982), "Output, Input, and Productivity Using Superlative Index Numbers,” Economic Journal, 92, 73-96.

Chen, Tain-Jy and De-Piao Tang (1987), “ Comparing Technical Efficiency between Import Substituting and Export-Oriented Foreign Firms in a Developing Country," Journal of Development Economics, 26, 277-289.

Clerides, Sofronis, Saul Lach, and James Tybout (forthcoming), "Is 'Learning-by-Exporting' Important? Micro-Dynamic Evidence from Colombia, Mexico and Morocco," Quarterly Journal of Economics.

Ericson, Richard and Ariel Pakes (1995), "Markov-Perfect Industry Dynamics: A Framework for Empirical Work," Review of Economic Studies, 62, 53-82.

Evenson, Robert E. and L.E. Westphal (1995), "Technological Change and Technology Strategy," in J. Behrman and T.N. Srinivasan (eds.), Handbook of Development Economics, Vol. 3A, Amsterdam: North-Holland. 
Good, David H., M. Ishaq Nadiri, and Robin Sickles (1996), "Index Number and Factor Demand Approaches to the Estimation of Productivity," NBER Working Paper 5790.

Grossman, Gene and Elhanan Helpman (1991), Innovation and Growth in the World Economy, Cambridge, MA: MIT Press.

Haddad, Mona (1993), "How Trade Liberalization Affected Productivity in Morocco," Policy Research Working Paper 1096, Policy Research Department, The World Bank, Washington, D.C.

Handoussa, James, Mieko Nishimizu, and John Page (1986), "Productivity Change in Egyptian Public Sector Industries after the 'Opening'," Journal of Development Economics, 20, 53-74.

Hobday, Michael (1995), Innovation in East Asia: The Challenge to Japan, Edward Elgar Publishing Limited.

Hopenhayn, Hugo (1992), "Entry, Exit, and Firm Dynamics in Long-Run Equilibrium,” Econometrica, 60, 1127-50.

Jovanovic, Boyan (1982), "Selection and the Evolution of Industry," Econometrica, 50, 649-670.

Lambson, Val E. (1991), "Industry Evolution With Sunk Costs and Uncertain Market Conditions," International Journal of Industrial Organization, 9, 171-196.

Levy, Brian (1988), "Korea and Taiwan as International Competitors: The Challenges Ahead," The Columbia Journal of World Business, 23.

Levy, Brian (1991), "Transactions Costs, the Size of Firms and Industrial Policy: Lessons from a Comparative Case Study of the Footwear industry in Korea and Taiwan," Journal of Development Economics, 34, 151-178.

Levy, Brian and Wen-Jeng Kuo (1991), "The Strategic Orientation of Firms and the Performance of Korea and Taiwan in Frontier Industries," World Development.

Pack, Howard (1992), "New Perspectives on Industrial Growth in Taiwan," in Gustav Ranis (ed.), Taiwan From Developing to Mature Economy, Westview Press.

Pack, Howard and Larry Westphal (1986), "Industrial Strategy and Technical Change: Theory versus Reality,"Journal of Development Economics, 22, 87-128.

Rhee, Yung W., Bruce Ross-Larson and Garry Pursell (1984), Korea's Competitive Edge: Managing the Entry into World Markets, Baltimore, MD: Johns Hopkins University Press.

Richardson, J. David and Karin Rindal (1995), Why Exports Really Matter! Institute for International Economics and The Manufacturing Institute.

Richardson, J. David and Karin Rindal (1996), Why Exports Matter: More! Institute for International Economics and The Manufacturing Institute. 
Roberts, Mark J. and James R. Tybout, eds. (1996), Industrial Evolution in Developing Countries: Micro Patterns of Turnover, Productivity, and Market Structure, Oxford: Oxford University Press.

Roberts, Mark J. and James R. Tybout (1997), "The Decision to Export in Colombia: An Empirical Model of Entry with Sunk Costs," American Economic Review, 87, 545-564.

Rodrik, Dani (1995), “Getting Interventions Right: How South Korea and Taiwan Grew Rich,” Economic Policy, 20, 55-107.

Tybout, James R. (1996), "Heterogeneity and Productivity Growth: Assessing the Evidence," in Industrial Evolution in Developing Countries: Micro Patterns of Turnover, Productivity, and Market Structure, edited by Mark J. Roberts and James R. Tybout, Oxford University Press.

Tybout, James R. and M. Daniel Westbrook (1995), "Trade Liberalization and Dimensions of Efficiency Change in Mexican Manufacturing Industries." Journal of International Economics, 31, 53-78.

Westphal, Larry (1990), "Industrial Policy in an Export-Propelled Economy: Lessons from South Korea's Experience," Journal of Economic Perspectives, 4, 41-59.

World Bank (1993), The East Asian Miracle: Economic Growth and Public Policy, Oxford: Oxford University Press for the World Bank. 
$\underline{\text { Table } 1}$

Percentage Difference in Average Productivity Between Exporters and Nonexporters (standard error of the difference in parentheses)

[Number of Exporters/Number of Nonexporters]

\begin{tabular}{|l|c|c|c|c|c|}
\hline & \multicolumn{2}{|c|}{ Taiwan } & \multicolumn{3}{c|}{ Korea } \\
\hline & 1986 & 1991 & 1983 & 1988 & 1993 \\
\hline Textiles & $.276(.010)$ & $.186(.010)$ & $.311(.017)$ & $.234(.014)$ & $.231(.014)$ \\
& {$[1231 / 2039]$} & {$[946 / 2589]$} & {$[510 / 1368]$} & {$[874 / 1767]$} & {$[1163 / 2352]$} \\
\hline Apparel & $.247(.011)$ & $.196(.013)$ & $.189(.022)$ & $.153(.018)$ & $.199(.019)$ \\
& {$[809 / 1171]$} & {$[571 / 1465]$} & {$[257 / 1479]$} & {$[499 / 1852]$} & {$[479 / 2212]$} \\
\hline Plastics & $.166(.006)$ & $.151(.007)$ & $.148(.027)$ & $.097(.016)$ & $.071(.014)$ \\
& {$[1806 / 4811]$} & {$[1497 / 7470]$} & {$[193 / 1171]$} & {$[481 / 2109]$} & {$[572 / 3563]$} \\
\hline $\begin{array}{l}\text { Electrical Machinery/ } \\
\text { Electronics }\end{array}$ & $.118(.007)$ & $.145(.006)$ & $.068(.021)$ & $.039(.013)$ & $.045(.011)$ \\
& {$[2024 / 3354]$} & {$[2347 / 5703]$} & {$[385 / 933]$} & {$[880 / 1917]$} & {$[1149 / 3735]$} \\
\hline Transportation Equip & $.126(.010)$ & $.153(.011)$ & $.140(.036)$ & $.110(.021)$ & $.094(.017)$ \\
& {$[606 / 1751]$} & {$[678 / 2565]$} & {$[98 / 507]$} & {$[248 / 1003]$} & {$[266 / 2045]$} \\
\hline
\end{tabular}


Table 2

Average Productivity Differences Across Plants Based on Export Intensity

(standard errors in parentheses)

\begin{tabular}{|c|c|c|c|c|c|}
\hline \multicolumn{6}{|c|}{ Taiwan } \\
\hline \multirow{2}{*}{ Industry } & \multirow{2}{*}{ Intercept } & \multicolumn{3}{|c|}{ Export Intensity Categories ${ }^{\mathrm{a}}$} & \multirow[t]{2}{*}{ Test Results ${ }^{\mathrm{b}}$} \\
\hline & & Low & Medium & High & \\
\hline Textiles & $\begin{array}{l}-.012 \\
(.005)\end{array}$ & $\begin{array}{l}.236 \\
(.014)\end{array}$ & $\begin{array}{l}.212 \\
(.012)\end{array}$ & $\begin{array}{l}.244 \\
(.009)\end{array}$ & 12 \\
\hline Apparel & $\begin{array}{l}-.142 \\
(.007)\end{array}$ & $\begin{array}{l}.181 \\
(.027)\end{array}$ & $\begin{array}{l}.193 \\
(.018)\end{array}$ & $\begin{array}{l}.233 \\
(.009)\end{array}$ & 2 \\
\hline Plastics & $\begin{array}{l}.012 \\
(.003) \\
\end{array}$ & $\begin{array}{l}.145 \\
(.010) \\
\end{array}$ & $\begin{array}{l}.141 \\
(.009)\end{array}$ & $\begin{array}{l}.170 \\
(.006)\end{array}$ & 2 \\
\hline $\begin{array}{l}\text { Electrical Machinery/ } \\
\text { Electronics }\end{array}$ & $\begin{array}{l}-.007 \\
(.004)\end{array}$ & $\begin{array}{l}.145 \\
(.009)\end{array}$ & $\begin{array}{l}.129 \\
(.007)\end{array}$ & $\begin{array}{l}.131 \\
(.006)\end{array}$ & 123 \\
\hline Transportation Equip & $\begin{array}{l}-.140 \\
(.005)\end{array}$ & $\begin{array}{l}.179 \\
(.015)\end{array}$ & $\begin{array}{l}.121 \\
(.014)\end{array}$ & $\begin{array}{l}.133 \\
(.010)\end{array}$ & 3 \\
\hline \multicolumn{6}{|c|}{ Korea } \\
\hline & \multirow{2}{*}{ Intercept } & \multicolumn{3}{|c|}{ Export Intensity Categories ${ }^{\mathrm{a}}$} & Test Results ${ }^{\mathrm{b}}$ \\
\hline & & Low & Medium & High & \\
\hline Textiles & $\begin{array}{l}-.118 \\
(.009) \\
\end{array}$ & $\begin{array}{l}.188 \\
(.018) \\
\end{array}$ & $\begin{array}{l}.228 \\
(.014) \\
\end{array}$ & $\begin{array}{c}.281 \\
(.011) \\
\end{array}$ & 2 \\
\hline Apparel & $\begin{array}{l}-.068 \\
(.009)\end{array}$ & $\begin{array}{l}.242 \\
(.037) \\
\end{array}$ & $\begin{array}{l}.176 \\
(.030) \\
\end{array}$ & $\begin{array}{l}.173 \\
(.013) \\
\end{array}$ & 123 \\
\hline Plastics & $\begin{array}{l}-.067 \\
(.009)\end{array}$ & $\begin{array}{l}.092 \\
(.014)\end{array}$ & $\begin{array}{c}.084 \\
(.016)\end{array}$ & $\begin{array}{l}.111 \\
(.020)\end{array}$ & 123 \\
\hline $\begin{array}{l}\text { Electrical Machinery/ } \\
\text { Electronics }\end{array}$ & $\begin{array}{l}-.079 \\
(.009) \\
\end{array}$ & $\begin{array}{c}.058 \\
(.013) \\
\end{array}$ & $\begin{array}{c}.024 \\
(.013) \\
\end{array}$ & $\begin{array}{c}.055 \\
(.012) \\
\end{array}$ & 123 \\
\hline Transportation Equip & $\begin{array}{l}-.070 \\
(.013)\end{array}$ & $\begin{array}{c}.094 \\
(.017)\end{array}$ & $\begin{array}{c}.085 \\
(.024)\end{array}$ & $\begin{array}{c}.202 \\
(.033)\end{array}$ & 2 \\
\hline
\end{tabular}

All regressions include year dummy variables.

a) Low: $\quad 0<$ Export Share $\leq .25$

Medium: $.25<$ Export Share $\leq .75$

High: $\quad .75<$ Export Share b) (1) do not reject equality of all 3 export intensity parameters at $\alpha=.05$ level

(2) do not reject equality of low and medium export intensity coefficients at the $\alpha=.05$ level

(3) do not reject quality of medium and high export intensity coefficients at the $\alpha=.05$ level. 
Table 3

Average Productivity Differences Based on Transitions In or Out of the Export Market (standard errors in parentheses)

\begin{tabular}{|c|c|c|c|c|}
\hline \multicolumn{5}{|c|}{ Taiwan } \\
\hline & \multirow{2}{*}{ Intercept } & \multicolumn{3}{|c|}{ Differential for Plants that } \\
\hline & & $\begin{array}{l}\text { Exit Export } \\
\text { Market }\end{array}$ & $\begin{array}{c}\text { Enter Export } \\
\text { Market }\end{array}$ & $\begin{array}{c}\text { Remain in Export } \\
\text { Market }\end{array}$ \\
\hline Textiles & $\begin{array}{l}.150 \\
(.005)\end{array}$ & $\begin{array}{l}.103 \\
(.021)\end{array}$ & $\begin{array}{l}.173 \\
(.012)\end{array}$ & $\begin{array}{l}.223 \\
(.014)\end{array}$ \\
\hline Apparel & $\begin{array}{l}-.018 \\
(.007)\end{array}$ & $\begin{array}{c}.064 \\
(.028)\end{array}$ & $\begin{array}{l}.189 \\
(.015)\end{array}$ & $\begin{array}{l}.219 \\
(.020)\end{array}$ \\
\hline Plastics & $\begin{array}{l}.069 \\
(.003)\end{array}$ & $\begin{array}{l}.082 \\
(.014)\end{array}$ & $\begin{array}{l}.138 \\
(.008)\end{array}$ & $\begin{array}{l}.196 \\
(.012)\end{array}$ \\
\hline $\begin{array}{l}\text { Electrical Machinery/ } \\
\text { Electronics }\end{array}$ & $\begin{array}{l}.186 \\
(.003)\end{array}$ & $\begin{array}{l}.044 \\
(.014)\end{array}$ & $\begin{array}{l}.138 \\
(.007)\end{array}$ & $\begin{array}{l}.167 \\
(.009)\end{array}$ \\
\hline Transportation Equip & $\begin{array}{l}-.205 \\
(.005)\end{array}$ & $\begin{array}{l}.080 \\
(.023)\end{array}$ & $\begin{array}{l}.133 \\
(.013)\end{array}$ & $\begin{array}{l}.211 \\
(.018)\end{array}$ \\
\hline \multicolumn{5}{|c|}{ Korea } \\
\hline Textiles & $\begin{array}{l}-.112 \\
(.008) \\
\end{array}$ & $\begin{array}{l}.115 \\
(.030) \\
\end{array}$ & $\begin{array}{l}.240 \\
(.012) \\
\end{array}$ & $\begin{array}{l}.209 \\
(.017) \\
\end{array}$ \\
\hline Apparel & $\begin{array}{l}-.061 \\
(.008) \\
\end{array}$ & $\begin{array}{c}.131 \\
(.047) \\
\end{array}$ & $\begin{array}{c}.186 \\
(.015) \\
\end{array}$ & $\begin{array}{c}.121 \\
(.030) \\
\end{array}$ \\
\hline Plastics & $\begin{array}{l}-.040 \\
(.006)\end{array}$ & $\begin{array}{l}.004^{*} \\
(.028)\end{array}$ & $\begin{array}{c}.077 \\
(.012)\end{array}$ & $\begin{array}{l}.102 \\
(.022)\end{array}$ \\
\hline $\begin{array}{l}\text { Electrical Machinery/ } \\
\text { Electronics }\end{array}$ & $\begin{array}{l}-.025 \\
(.007) \\
\end{array}$ & $\begin{array}{l}-.032^{*} \\
(.026) \\
\end{array}$ & $\begin{array}{c}.037 \\
(.009) \\
\end{array}$ & $\begin{array}{c}.056 \\
(.016) \\
\end{array}$ \\
\hline Transportation Equip & $\begin{array}{l}-.022 \\
(.009)\end{array}$ & $\begin{array}{l}-.018^{*} \\
(.038)\end{array}$ & $\begin{array}{c}.086 \\
(.016)\end{array}$ & $\begin{array}{c}.149 \\
(.029)\end{array}$ \\
\hline
\end{tabular}

All regressions contain year dummies.

"Do not reject that the coefficient equals zero at the $\alpha=.05$ significance level. 
$\underline{\text { Table } 4}$

Average Productivity Differences Between Entrants and Nonentrants to Export Market (standard errors in parentheses)

\begin{tabular}{|c|c|c|c|}
\hline \multicolumn{4}{|c|}{ Taiwan } \\
\hline & Intercept & $\begin{array}{c}\text { Entering Firm } \\
\text { Differential-- } \\
\text { Pre Entry }\end{array}$ & $\begin{array}{l}\text { Change in } \\
\text { Differential } \\
\text { Post Entry }\end{array}$ \\
\hline Textiles & $\begin{array}{l}-.007 \\
(.010)\end{array}$ & $\begin{array}{l}.060 \\
(.026)\end{array}$ & $\begin{array}{l}.083 \\
(.037)\end{array}$ \\
\hline Apparel & $\begin{array}{l}-.163 \\
(.013)\end{array}$ & $\begin{array}{l}.148 \\
(.044)\end{array}$ & $\begin{array}{l}-.026^{*} \\
(.062)\end{array}$ \\
\hline Plastics & $\begin{array}{l}.018 \\
(.005)\end{array}$ & $\begin{array}{c}.076 \\
(.015)\end{array}$ & $\begin{array}{c}.061 \\
(.021)\end{array}$ \\
\hline $\begin{array}{l}\text { Electrical Machinery/ } \\
\text { Electronics }\end{array}$ & $\begin{array}{c}.007 \\
(.008)\end{array}$ & $\begin{array}{l}.048 \\
(.016)\end{array}$ & $\begin{array}{l}.060 \\
(.023)\end{array}$ \\
\hline Transportation Equip & $\begin{array}{l}-.134 \\
(.010)\end{array}$ & $\begin{array}{c}.099 \\
(.028)\end{array}$ & $\begin{array}{l}.025^{*} \\
(.039)\end{array}$ \\
\hline \multicolumn{4}{|c|}{ Korea } \\
\hline Textiles & $\begin{array}{l}-.143 \\
(.013)\end{array}$ & $\begin{array}{l}.176 \\
(.024)\end{array}$ & $\begin{array}{l}.059^{*} \\
(.033)\end{array}$ \\
\hline Apparel & $\begin{array}{l}.014 \\
(.019)\end{array}$ & $\begin{array}{l}.036^{*} \\
(.052)\end{array}$ & $\begin{array}{l}.111^{*} \\
(.074)\end{array}$ \\
\hline Plastics & $\begin{array}{l}-.024 \\
(.014)\end{array}$ & $\begin{array}{l}.058 \\
(.027)\end{array}$ & $\begin{array}{l}.008^{*} \\
(.038)\end{array}$ \\
\hline $\begin{array}{l}\text { Electrical Machinery/ } \\
\text { Electronics }\end{array}$ & $\begin{array}{l}-.006 \\
(.019)\end{array}$ & $\begin{array}{l}.016^{*} \\
(.026)\end{array}$ & $\begin{array}{l}.027^{*} \\
(.036)\end{array}$ \\
\hline Transportation Equip & $\begin{array}{l}-.036 \\
(.024)\end{array}$ & $\begin{array}{l}.115 \\
(.039)\end{array}$ & $\begin{array}{l}-.002^{*} \\
(.053)\end{array}$ \\
\hline
\end{tabular}

All regressions contain year dummies.

*Do not reject the coefficient equals zero at the $\alpha=.05$ significance level. 
Table 5

Average Productivity Differences Between Exits and Continuing Exporters (standard errors in parentheses)

\begin{tabular}{|c|c|c|c|}
\hline \multicolumn{4}{|c|}{ Taiwan } \\
\hline Industry & Intercept & $\begin{array}{c}\text { Exiting Firm } \\
\text { Differential-- } \\
\text { Pre Exit }\end{array}$ & $\begin{array}{c}\text { Change in } \\
\text { Differential } \\
\text { Post Exit }\end{array}$ \\
\hline Textiles & $\begin{array}{l}.302 \\
(.012)\end{array}$ & $\begin{array}{l}-.121 \\
(.022)\end{array}$ & $\begin{array}{l}.001^{*} \\
(.031)\end{array}$ \\
\hline Apparel & $\begin{array}{l}.144 \\
(.016)\end{array}$ & $\begin{array}{l}-.131 \\
(.029)\end{array}$ & $\begin{array}{l}-.024^{*} \\
(.040)\end{array}$ \\
\hline Plastics & $\begin{array}{l}.209 \\
(.010)\end{array}$ & $\begin{array}{l}-.070 \\
(.016)\end{array}$ & $\begin{array}{l}-.045 \\
(.022)\end{array}$ \\
\hline $\begin{array}{l}\text { Electrical Machinery/ } \\
\text { Electronics }\end{array}$ & $\begin{array}{c}.152 \\
(.007) \\
\end{array}$ & $\begin{array}{l}-.069 \\
(.014) \\
\end{array}$ & $\begin{array}{l}-.054 \\
(.019) \\
\end{array}$ \\
\hline Transportation Equip & $\begin{array}{c}.030 \\
(.015)\end{array}$ & $\begin{array}{l}-.062 \\
(.025)\end{array}$ & $\begin{array}{l}-.070 \\
(.035)\end{array}$ \\
\hline \multicolumn{4}{|c|}{ Korea } \\
\hline Textiles & $\begin{array}{l}.200 \\
(.017)\end{array}$ & $\begin{array}{l}-.083 \\
(.025)\end{array}$ & $\begin{array}{l}-.001^{*} \\
(.034)\end{array}$ \\
\hline Apparel & $\begin{array}{l}.125 \\
(.032)\end{array}$ & $\begin{array}{l}.076^{*} \\
(.043)\end{array}$ & $\begin{array}{l}-.076^{*} \\
(.058)\end{array}$ \\
\hline Plastics & $\begin{array}{l}.230 \\
(.032)\end{array}$ & $\begin{array}{l}-.041^{*} \\
(.033)\end{array}$ & $\begin{array}{l}-.047^{*} \\
(.044)\end{array}$ \\
\hline $\begin{array}{l}\text { Electrical Machinery/ } \\
\text { Electronics }\end{array}$ & $\begin{array}{c}.068 \\
(.023)\end{array}$ & $\begin{array}{l}-.090 \\
(.027)\end{array}$ & $\begin{array}{l}.012^{*} \\
(.037)\end{array}$ \\
\hline Transportation Equip & $\begin{array}{l}.153 \\
(.035)\end{array}$ & $\begin{array}{l}-.053^{*} \\
(.039)\end{array}$ & $\begin{array}{l}-.091^{*} \\
(.053)\end{array}$ \\
\hline
\end{tabular}

All regressions contain year dummies.

*Do not reject the coefficient equals zero at the $\alpha=.05$ significance level. 
$\underline{\text { Table } 6}$

Average Productivity Differences Between Continuous Exporters and Continuous Nonexporters (standard errors in parentheses)

\begin{tabular}{|c|c|c|c|}
\hline \multicolumn{4}{|c|}{ Taiwan } \\
\hline \multirow[b]{2}{*}{ Industry } & \multirow[b]{2}{*}{ Intercept } & \multicolumn{2}{|c|}{ Exporting Firm Differential } \\
\hline & & Initial Year & $\begin{array}{c}\text { Change in Differential } \\
\text { Over Time }\end{array}$ \\
\hline Textiles & $\begin{array}{l}-.007^{*} \\
(.010)\end{array}$ & $\begin{array}{l}.309 \\
(.016)\end{array}$ & $\begin{array}{l}-.094 \\
(.023)\end{array}$ \\
\hline Apparel & $\begin{array}{l}-.163 \\
(.013)\end{array}$ & $\begin{array}{c}.307 \\
(.021)\end{array}$ & $\begin{array}{l}-.063 \\
(.030)\end{array}$ \\
\hline Plastics & $\begin{array}{l}.018 \\
(.005)\end{array}$ & $\begin{array}{l}.191 \\
(.012)\end{array}$ & $\begin{array}{l}-.002^{*} \\
(.017)\end{array}$ \\
\hline $\begin{array}{l}\text { Electrical Machinery/ } \\
\text { Electronics }\end{array}$ & $\begin{array}{l}.007^{*} \\
(.007)\end{array}$ & $\begin{array}{l}.145 \\
(.011)\end{array}$ & $\begin{array}{r}.011^{*} \\
(.015)\end{array}$ \\
\hline Transportation Equip & $\begin{array}{l}-.134 \\
(.010) \\
\end{array}$ & $\begin{array}{c}.165 \\
(.019) \\
\end{array}$ & $\begin{array}{l}.042^{*} \\
(.027) \\
\end{array}$ \\
\hline \multicolumn{4}{|c|}{ Korea } \\
\hline Textiles & $\begin{array}{l}-.134 \\
(.011)\end{array}$ & $\begin{array}{l}.316 \\
(.017)\end{array}$ & $\begin{array}{l}.013^{*} \\
(.025)\end{array}$ \\
\hline Apparel & $\begin{array}{c}.006 \\
(.016)\end{array}$ & $\begin{array}{l}.141 \\
(.032)\end{array}$ & $\begin{array}{l}-.017^{*} \\
(.050)\end{array}$ \\
\hline Plastics & $\begin{array}{l}-.013 \\
(.014)\end{array}$ & $\begin{array}{l}.188 \\
(.027)\end{array}$ & $\begin{array}{l}-.032^{*} \\
(.046)\end{array}$ \\
\hline $\begin{array}{l}\text { Electrical Machinery/ } \\
\text { Electronics }\end{array}$ & $\begin{array}{c}.017 \\
(.019)\end{array}$ & $\begin{array}{l}.044^{*} \\
(.024)\end{array}$ & $\begin{array}{l}.017^{*} \\
(.035)\end{array}$ \\
\hline Transportation Equip & $\begin{array}{l}-.046 \\
(.024)\end{array}$ & $\begin{array}{c}.167 \\
(.038)\end{array}$ & $\begin{array}{c}.037^{*} \\
(.057)\end{array}$ \\
\hline
\end{tabular}

All regressions contain year dummies.

${ }^{*}$ Do not reject the coefficient equals zero at the $\alpha=.05$ significance level. 